STATEMENT OF

\author{
C. D. ZERBY, DIRECTOR \\ OFFICE OF WASTE ISOLATION \\ UNION CARBIDE CORPORATION, NUCLEAR DIVISION
}

\title{
BEFORE THE
}

CALIFORNIA ENERGY RESOURCES CONSERVATION AND DEVELOPMENT COMMISSION

Sacramento, California

March 21, 1977

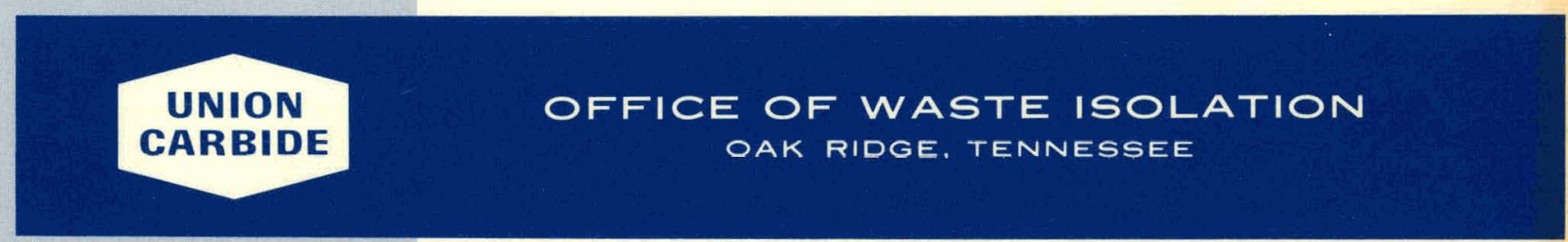

prepared for the U.S. ENERGY RESEARCH AND DEVELOPMENT ADMINISTRATION under U.S. GOVERNMENT Contract W-7405 eng 26 


\section{DISCLAIMER}

This report was prepared as an account of work sponsored by an agency of the United States Government. Neither the United States Government nor any agency Thereof, nor any of their employees, makes any warranty, express or implied, or assumes any legal liability or responsibility for the accuracy, completeness, or usefulness of any information, apparatus, product, or process disclosed, or represents that its use would not infringe privately owned rights. Reference herein to any specific commercial product, process, or service by trade name, trademark, manufacturer, or otherwise does not necessarily constitute or imply its endorsement, recommendation, or favoring by the United States Government or any agency thereof. The views and opinions of authors expressed herein do not necessarily state or reflect those of the United States Government or any agency thereof. 


\section{DISCLAIMER}

Portions of this document may be illegible in electronic image products. Images are produced from the best available original document. 
This report was prepared as an account of work sponsored by the United States Government. Neither the United States nor the Energy Research and Development Administration, nor any of their employees, nor any of their contractors, subcontractors, or their employees, makes any warranty, express or implied, or assumes any legal liability or responsibility for the accuracy, completeness or usefulness of any information, apparatus, product or process disclosed, or represents that its use would not infringe privately owned rights. 


\section{PROGRAM OVERVIEW}

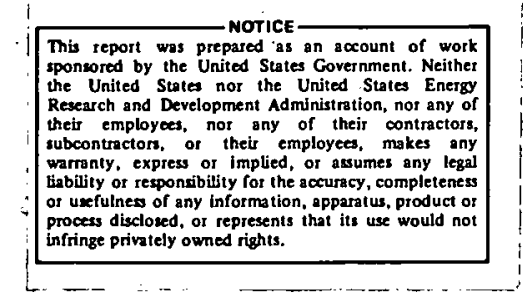

About a year ago, ERDA announced a greatly expanded program in the management of defense and commercial radioactive waste. At that time, the NWTS Program was created and assigned to ERDA - Oak Ridge Operations Office (ORO) for overall program coordination, and the Office of Waste Isolation (OWI) was created in Union Carbide Corporation - Nuclear Division (UCC-ND) at Oak Ridge, Tennessee, to manage the program.

The objective of the NWTS Program is to provide facilities in various deep geologic formations at multiple locations in the continental U.S.A. which will safely dispose of the commercial radioactive waste which must be delivered to a federal repository for terminal storage.

Although the NWTS Program was started only recently, deep geologic disposal studies have been under way for about 20 years. These studies began in 1957. when a National Academy of Sciences - National Research Council Advisory Committee suggested burial of solid radioactive wastes in natural salt deposits.* Since that time, this disposal method has been under continuous study and development including; in the late 1960s, an underground experiment with heaters and simulated waste in a bedded salt mine at Lyons, Kansas. $\therefore$ This experiment, which was called Project Salt Vault, was under the direction of Oak Ridge National Laboratory (ORNL), which is also operated by UCC-ND.

*Disposal of Radioactive Wastes on Land, Pub1. 519, National Academy of Sciences - National Research Council, Washington, D.C., 1957.

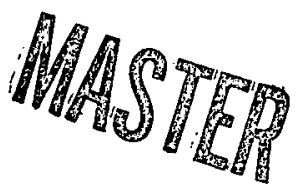


Project Salt Vault provided through its operating lifetime considerable information to verify the suitability of salt formations for geologic disposal of radioactive waste. Unfortunately, the Lyons, Kansas, site was not acceptable for a terminal storage facility because of the presence of unplugged boreholes and a nearby solution mining activity. As a result, a search for other suitable salt formations was started in the early 1970s which led to the identification of a location in the Permian Salt Basin 30. miles east of Carlsbad, New Mexico. This location is now being developed by Sandia as the Waste Isolation Pilot Plant (WIPP) for deep geologic disposal of low-level and intermediate-level radioactive waste from the defense program. The. WIPP project is not part of the NWTS Program. Currently OWI is continuing the search for other suitable locations for repositories in other salt and non-salt formations.

Salt formations that have been identified by OWI with potential for geologic disposal are shown in Figure 1. Of these, the Salina Formation, the interior province of the Gulf Coast domes, the Permian Basin, and the Paradox Basin are all considered to be formations with the highest potential based on the current information available. Figure 2 shows the argillaceous formations and Figure 3 shows the crystalline and volcanic formations with potential, which are also under study. Aitogether these formations underlie 45 of the 48 continental United States, and we expect to conduct studies in all of these states as part of the program to identify candidate sites.

Although the development sequence for a terminal storage facility may differ slightly from one geologic formation to another, the generalized 


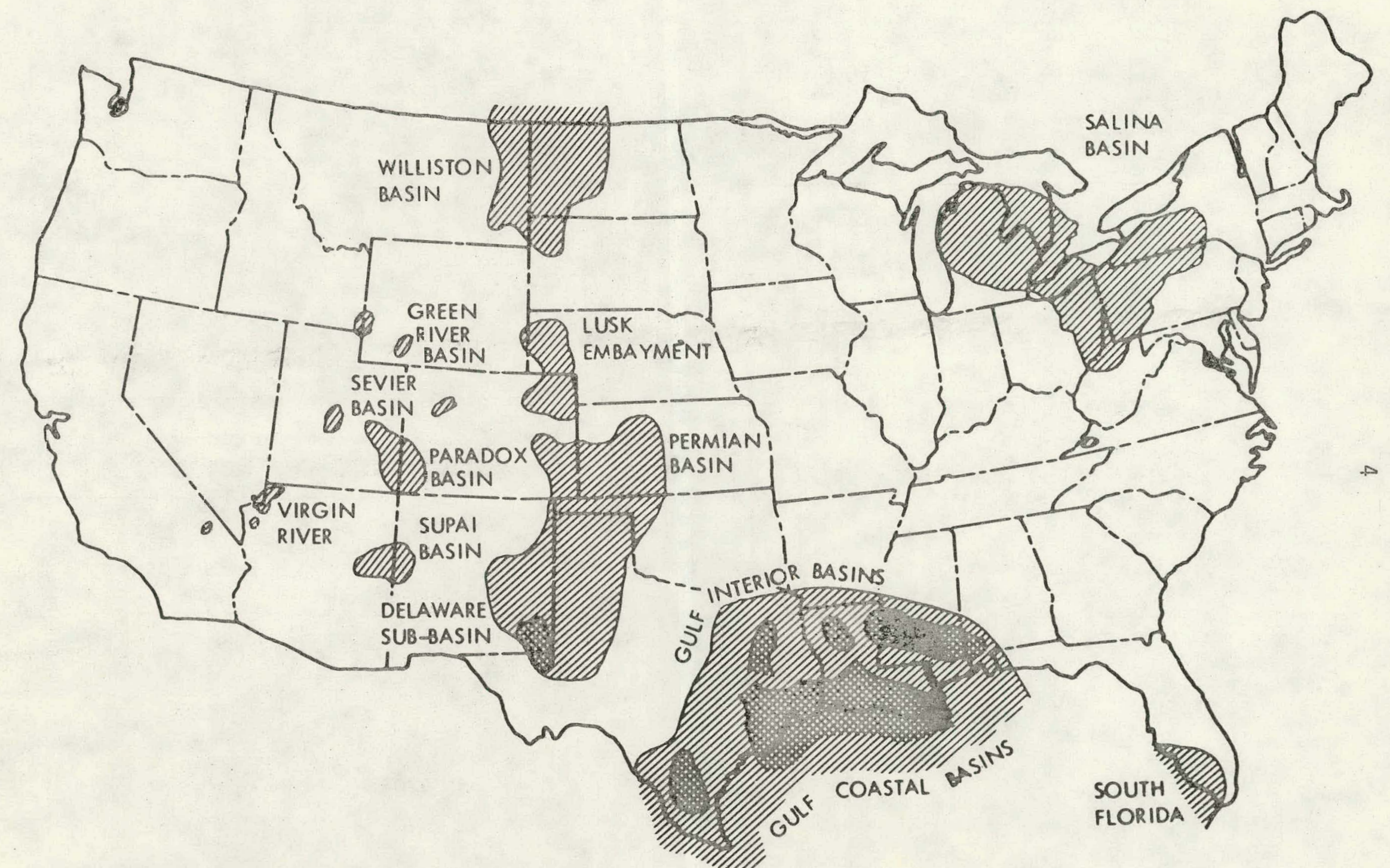

ROCK SALT DEPOSITS IN THE UNITED STATES

(AFTER PIERCE A.ND RICH, U.S.G.S. BULL. 1148)

Figure 1 


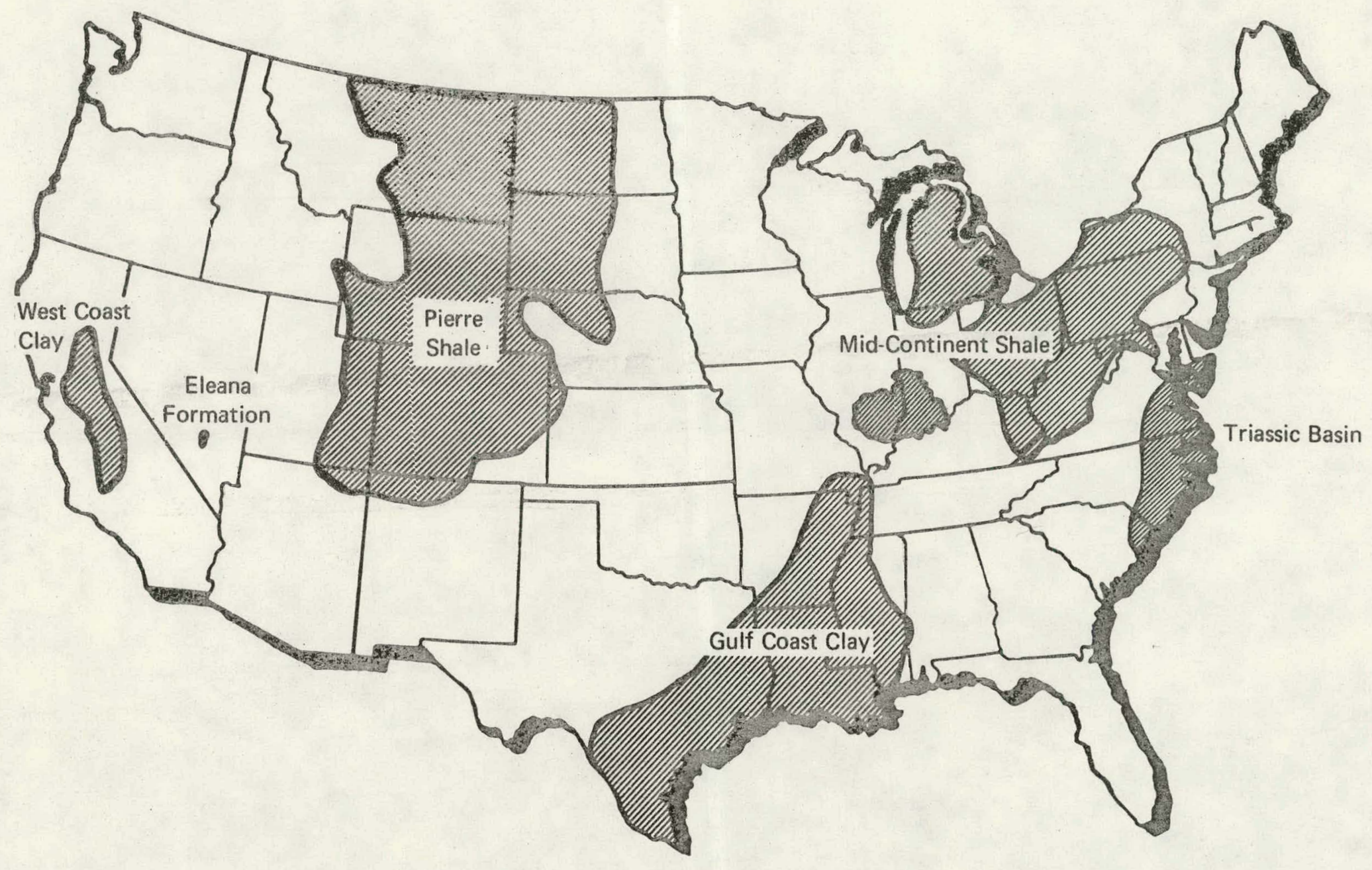

ARGILLACEOUS FORMATIONS IN THE UNITED STATES

OWI-76-26 R1

Figure 2 


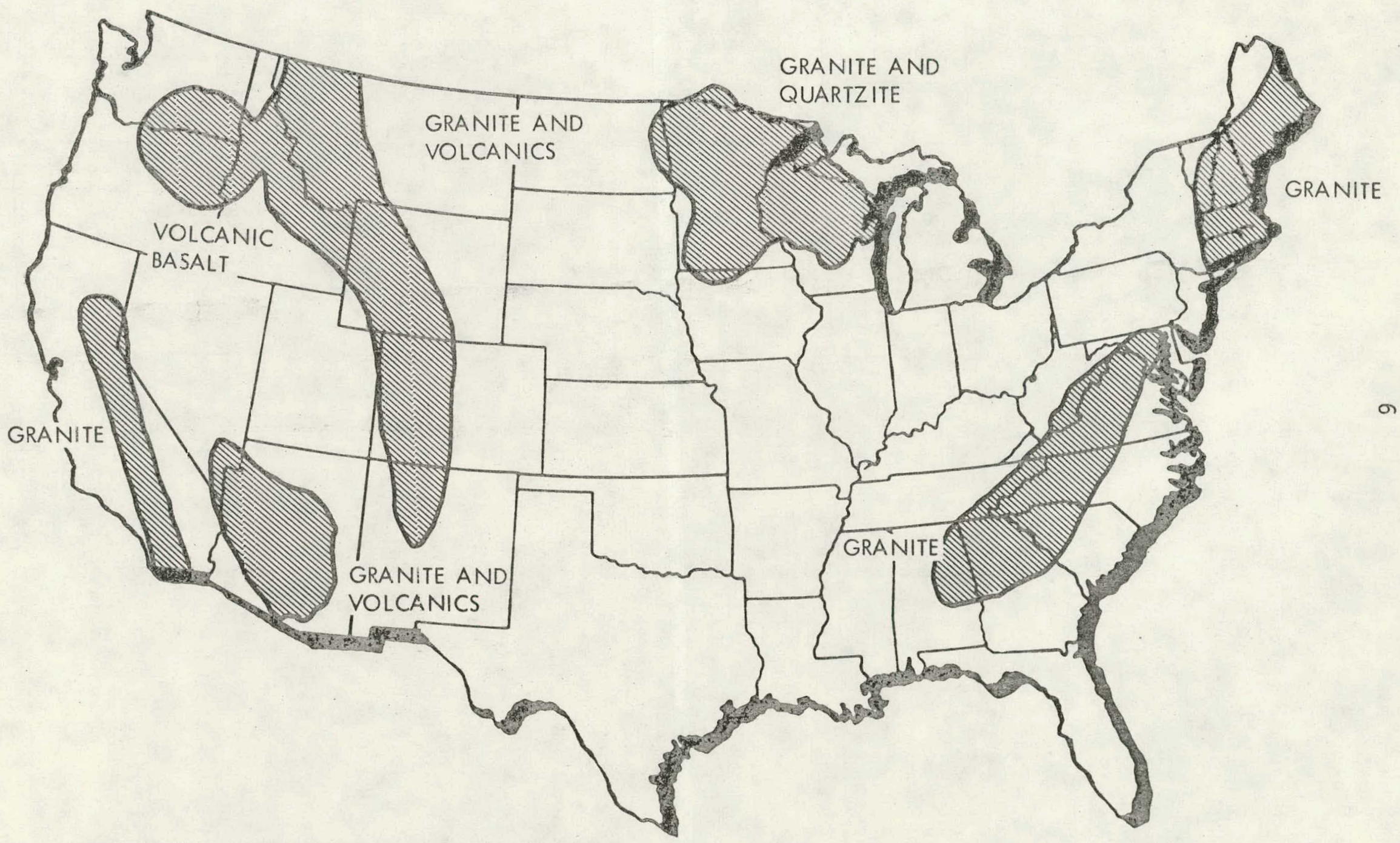

CRYSTALLINE FORMATIONS IN UNITED STATES

OWI-76-27

Figure 3 
sequence can be characterized as having six distinct steps as follows:

1. Identification of formations of interest

2. Reconnaissance studies (1iterature surveys)

3. In situ tests

4. Field area studies

5. Field detailed confirmation studies

6. Establishment of a repository

\section{Identification of Formations of Interest}

In the process of identifying formations of interest, a review is made first which is based solely on the general knowledge of the geologic properties and/or fundamental properties of the rock type involved. This review has been completed in part; leading to the identification of the formations shown in Figures 1 through 3. In addition to these, however, certain carbonate rocks are also under study.

\section{Reconnaissance Studies}

Next a reconnaissance study would be undertaken to collect all the available existing data on those properties and characteristics of the formation needed for waste disposal considerations. This information provides a regional evaluation of the potential for utilization of the formation for waste disposal and may inciude (1) structure, stratigraphy, depth, and thickness, (2) hydrology, (3) mineralogy/petrology, (4) natural resources, and (5) general surface characteristics. Based upon the information compiled at this stage, the prospects for the formation are evaluated and reviewed and a number of smaller, perhaps "county-size" regions are identified for further geologic area studies. 
In Situ Tests

Once the formation is identified as a possible candidate for waste disposal, a set of in situ experiments will be conducted in parallel with the geologic area studies ranging from simple electrical heaters placed in holes in exposed surface outcrops of the formation to extensively instrumented vault tests in excavations especially constructed at the expected depth of the repository. In general, the vault tests are constructed to permit tests with both electric heaters and/or canisters of simulated waste which are removed at the conclusion of the experiment. They provide extensive information on the physical behavior of the rock, the waste canister, as well as the stability of the underground layout. Project Salt Vault is an example of such a test.

\section{Field Area Studies}

The geologic area studies that follow the reconnaissance study are field activities designed to develop new and specific data in the areas of interest. These studies include (1) core drilling at a density of perhaps 6 to 10 holes per 1,000 square miles to obtain adequate definition of the important subsurface characteristics of the formation, (2) field geologic mapping, (3) hydrologic studies, (4) geophysical surveys, and (5) other geologic studies. Upon completion of these studies, the suitability of the area is again reviewed and if it still appears promising, one or more specific locations will be identified for more detailed confirmation investigations. There will be extensive reviews at this point involving all review groups that have been established. The selection by OWI and ERDA of specific locations for 
more detailed confirmation investigations and the final selection of repository sites will be firmly based on all these reviews as well as comments obtained during public meetings.

\section{Field Confirmation Studies}

The detailed confirmation studies are directed toward specific 10cations of perhaps 10-30 square miles each. The investigations involve primarily the drilling and testing of four or more core holes at each location, plus the continuation of any specific geologic studies for which the previous results are inadequate to evaluate the suitability of the location. The results of this phase of the investigation would be to technically qualify locations for consideration as repository sites.

\section{Establishment of A Repository}

After adequate review, a repository site will be selected and a facility will be designed and constructed. During the initial phase of operation of the repository; the facility will be limited in size. It will be heavily instrumented and it will keep the deposited waste in a retrievable state should there be any reason to remove it. Once the safety and stability of the configuration are confirmed, then the repository will be expanded to a full-scale operation and the retrievability will be abandoned.

At the present time, six repositories are scheduled for operation on the time schedule shown in figure 4. The solid triangle indicates when the search for the repository site will start. In the case of the 
GEOLOGIC TERMINAL STORAGE

GENERAL PLAN

\begin{tabular}{|c|c|c|c|c|c|c|c|c|c|c|c|c|c|c|c|c|c|c|c|}
\hline & FY.77 & FY.78 & FY-79 & FY- 80 & FY-81 & FY.82 & FY-83 & FY-84 & FY. B5 & FY-86| & FY.87 & FY-88 & FY-89 & FY.90 & FY.91 & FY.92 & FY.93 & FY.94| & FY-95 \\
\hline REPOSITORY 1 & & & & . & & & & & & INITIAL & L.PHAS & SE OPE & RATIO & & \multicolumn{5}{|c|}{ FULL-SCALE OPERATIONS } \\
\hline REPOSITORY 2 & & & & & & & & & & & & & & & & & & & \\
\hline REPOSITORY 3 & & & & & & & & & & & & & & & & & & & \\
\hline REPOSITORY 4 & & & & & & & & & & & & & & & & & & & \\
\hline REPOSITORY 5 & & & & & & & & & & & & & & & & & & & \\
\hline REPOSITORY 6 & & & & & & & & & & & & & & & & & & & \\
\hline & & & & & & & & & & & & & & & & & & & \\
\hline
\end{tabular}

ów1-76-31 R5 
first two repositories, candidate sites are to be identified by the end of FY 1978. This will be followed by final site selection, design and construction of the repository with initial-phase operation starting in FY 1985 under a license from NRC. The first two repositories are to be completed in salt. The parallel schedule for the first two repositories is to accommodate the retrievability mode of operation during the initial phase of operation. This provides another facility to accept the waste if it has to be removed from either for any reason. The remaining four facilities will be preferentially constructed in non-salt formations on schedules as indicated.

\section{GENERAL DESCRIPTION OF A REPOSITORY IN SALT}

At this point, I would like to provide you with a general description of a repository based on a recent Waste Isolation Facility Description in bedded salt.* In this description, as well as in the remainder of the presentation, I will limit my remarks to salt formations and sait repositories. This emphasis on salt reflects the current state of the art and does not in any way deemphasize current efforts lu find repository sites in other rock formations.

Figure 5 shows a cutaway sketch of the repository. The repository consists of a large number of rooms excavated at a depth which lies between 800 and approximately 3,000 feet below" the surface. The waste would be delivered to the surface facilities of the repository in a

*Parsons Brinkerhoff Quade \& Douglas, Inc., Waste Isulation Facility Description, Bedded Salt, Y/OWI/SUB-76/16505 (September 1976). 


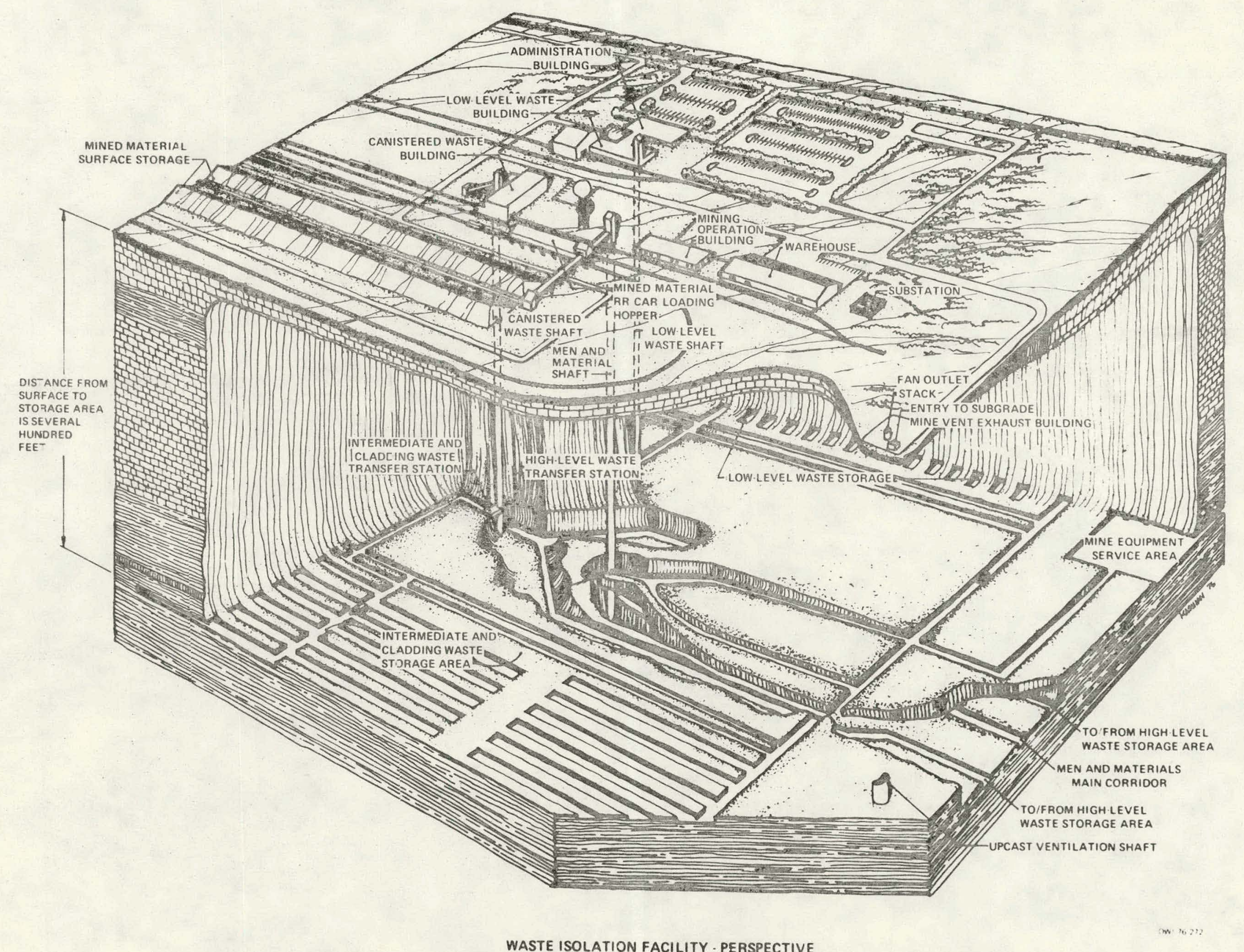

Figure 5 
solidified form in specially designed containers. Before being lowered to the disposal area through vertical shafts joining the surface to the mine, each container will be examined for damage and surface contamination and an overpack will be provided if necessary.

There are four shafts serving the repository. One is a ventilation shaft, one is a men-and-materials shaft to transport the workers and excavated rock, one is for low-level radioactive waste, and the last is to transport waste that must be handled remotely because of the level of radioactivity. In the case of the remotely handled waste, it will be unloaded from the delivering vehicle and lowered through the shaft to the disposal area, where it will be received by a shielded transporter vehicle. It will then be moved into one of the disposal rooms where it will be lowered into a hole in the floor of the room and the hole will be plugged for radiation protection. In the case of low-level waste, the containers will be lowered through the shaft and then stacked in the disposal rooms.

A1. the facilities at the repository will be designed to meet the requirements of the responsible regulatory agencies for handling radioactive materials and containment of these materials during both normal operation and emergency accident situations. This means that the surface facilities will be designed to maintain their integrity during natural disasters. Radiation monitoring devices will be maintained in operation inside the repository, on the surface, and outside the area to monitor for abnormal conditions. Charges for disposal services will be structured to provide funds for long-term radiation monitoring of the area after decommissioning. 
The reference repository will have an excavation that will underlie 2,000 acres. ERDA will acquire surface and subsurface title to this land. On the surface, the waste receiving and support buildings will occupy approximately 200 acres. This will be the only visible evidence of the repository. The remainder of the 2,000 acres may be leased for selective usage. Surrounding the 2,000-acre area overlying the excavation will be a controlled area two miles in width for which ERDA will only acquire subsurface title. This will permit all deep mining and drilling operations to be controlled, thus eliminating any compromise of the safety and integrity of the disposal area. Surface activities within the controlled area will be unrestricted.

The type of waste to be disposed of in the repository depends on the commercial fuel cycle adopted in the United States. If the fuel cycle is closed and reprocessing plants go into operation, then the repository will be designed to dispose of high-level radioactive waste (HLW) and transuranic (TRU) contaminated waste. The latter category is subdivided into three subcategories including cladding waste and intermediate-level radioactive waste (ILW), both of which must be handled remotely, and lowlevel radioactive waste (LLW). If, on the other hand, the once-through cycle is adopted, then the repository will be designed to dispose of spent fuel elements and the ILW resulting from reactor operations. In this case the containerized fuel elements will be handled remotely just like the high-level waste. 
In the case of the closed fuel cycle, the reference facility described in the preconceptual design will accommodate the following quantities of waste:

Type.

High Leve] (HLW)
Containers Container cubic meter

35,000 Canister

6,000

TRU Contaminated Waste

$\begin{array}{lrlr}\text { Cladding } & 58,000 & \text { Canister } & 10,000 \\ \text { Intermediate Level (ILW) } & 250,000 & \text { Carister } & 45,000 \\ \text { Low Level (LLW) } & 650,000 & \begin{array}{c}\text { (55-ga?. } \\ \text { drums) }\end{array} & 136,000 .\end{array}$

This is roughly, equivalent to all of the waste that would be produced through the year 2006 based on the scenario of 510,000 megawatts electrical production by nuclear power in the year 2000. Another way to put this is that the reference repository will dispose of the waste from approximately 3 million megawatt years of installed capacity at $70 \%$ capacity factor.

In the preconceptual design, a standard canister size was assumed for all waste that is handled remotely. This container is 12-in.-diameter stainless steel pipe (12.75 in. 0.D.) and is $10 \mathrm{ft}$ long. Each canister will contain about $0.18 \mathrm{~m}^{3}$ of waste. In future conceptual designs the size of the container will probably change after the needs of the industry are carefully evaluated.

The excavated disposal area of the repository encompasses apprnximately 2,000 acres and is shown schematically in figure 6 . The percent 


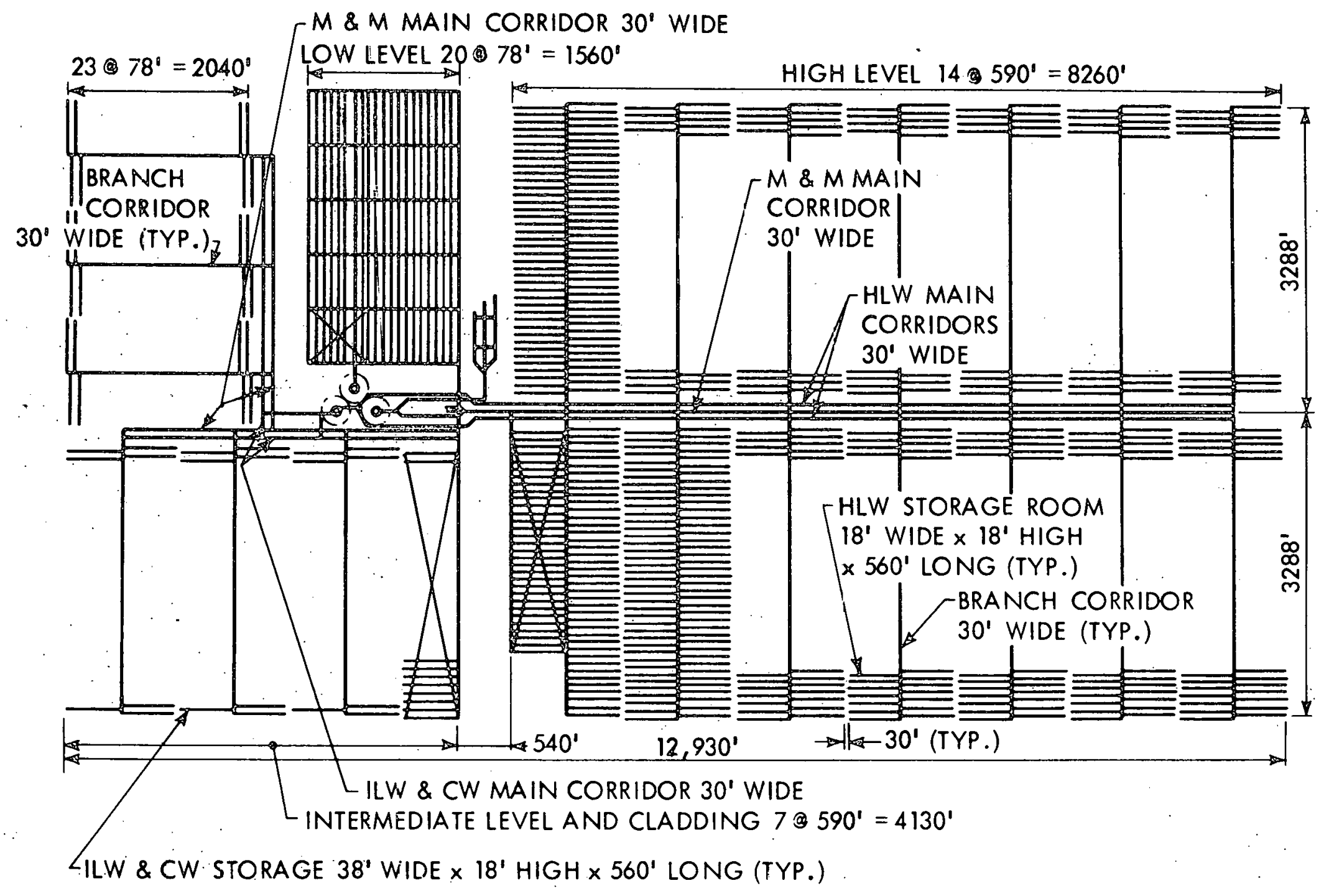

MINE MASTER PLAN

(GENERIC REPOSITORY DESCRIPTION)

Figure 6 
of the area committed to the various waste types are $70 \%$ for $H L W, 25 \%$ for cladding and ILW, and 5\% for LLW. The mine layout and storage sequence design is a conventional room-and-pillar layout and incorporates the requirements of mine ventilation, mine opening stability, thermal effects, and efficient use of excavated space and of mining and haulage equipment. A modular approach to the mine development allows the simultaneous conduction of mining activities and waste storage operations, where excavation of one "panel" of storage rooms proceeds without interfering with the conduction of storage operations in the previously excavated panels. All mining activities involved in initial-phase repository construction.will be completed prior to emplacement of any radioactive wastes. In the vicinity of the shafts and mined material conveyors, the construction corridors and waste haulage corridors are separated vertically by about 70 feet to ensure that they do not intersect. This not only simplifies traffic patterns in the mine, but also acts as a safety feature by separating the mining and waste handling activities.

To guarantee shaft stability, a 150-ft-radius safety zone is designated around each shaft. Ali traveiways, except those leading to the shafts, pass outside this zone.

All storage rooms receiving canisters are designed to have only one entry. This provides positive control for heat, ventilation, and exhaust for each room. Rooms for LLW storage are designed as an open-grid system to permit easy storage without degrading ventilation performance. 
The HLW mine is located to minimize heat effects on the operation of the shafts or on mine areas for other waste types. Access to the mine consists of two HLW main corridors originating at the receiving station at the HLW shaft. The men-and-materials main corridor runs between these two corridors. Each HLW main corridor connects with branch corridors from which extend the storage rooms. Thirty-two canisters will be stored in each room in vertical holes bored in the centerline of each room on 17 -ft centers.

During the initial phase of operation of the repository, the waste will be retained in a retrievable mode so it can be removed from the repository with relative ease should circumstances develop that require this action. After the repository has operated for a period of time and no unexpected difficulties have occurred, the retrievable mode will be abandoned and the rooms which have been filled with waste will be backfilled with salt and sealed. When the repository is full, the surface facilities will be decommissioned and dismantled, and all shafts will be plugged and sealed. The location will then be permanently marked.

It should be noted that it is a basic assumption of this approach that the geologic formation provides the means of containment over the hazardous lifetime of the waste. The container or canister and the solidified form of the waste are basic requirements only for safety during transportation, handling, and while the waste is retained in a retrievable mode. 


\section{GEOLOGIC PROPERTIES OF SALT FORMATIONS \\ IMPORTANT FOR WASTE DISPOSAL}

Now I want to turn to the geological properties of salt which are important for waste disposal and which form the basis of the search for repository sites. Salt, or halite $(\mathrm{NaCl})$, has several basic properties which make it fundamentally suitable for geologic disposal, and these are its plasticity, its good thermal conductivity, and its ease of mining. Because of its plasticity, or ability to flow under relatively mild conditions of heat and pressure, sizable strains can be absorbed without fracture, while at the same time reducing the strain transmitted to the surrounding rocks. However, in the highly unlikely case that a sudden tectonic event (or ground movement) should cause the salt to rupture, its plasticity will allow it to flow into the ruptured area and, as the salt recrystallizes, effectively reseal the rupture.

Salt has the highest thermal conductivity of any type of common rock, a characteristic which allows the heat generated by the waste to be rapidly transmitted away or dispersed. Consequently, for any given maximum repository temperature, it will be possible to pack waste canisters more closely together than in other rocks, considerably decreasing the amount of mining necessary.

Salt mining is one of the nost efficientily operated underground extractive industries; almost all known mining techniques can be used with a high degree of efficiency. The construction cost of a repository in 
salt would represent only a small fraction of the cost in some other rock types, such as granite or basalt.

Vast deposits of salt have been formed in a number of different sedimentary basins in the United States as a result of the natural evaporation of seawater in the distant geologic past. As shown in Figure 1, these deposits occur either as bedded or domed salt. Both types of salt formations have potential for terminal waste storage. Although all the deposits share certain characteristics, they also possess enough differences to make each salt deposit unique. These differences give rise to the need for determining selection factors to be used as a basis for evaluating the deposits for their waste storage potential. I will briefly describe the selection factors identified for salt. In general, these factors apply to both bedded and domed salt.

\section{Depth to Disposal Horizon}

The depth to the formation selected for the repository, that is, the disposal horizon, should be adequate to isolate the waste and the encapsulating rock unit from all surface phenomena such as erosion and denudation. At the same time, the depth should not be so great that the stability of the mine openings would be jeopardized as a result of overburden pressure. Also, the depth should be chosen to facilitate maximum mining capability since operations in salt become more difficult and more expensive as the depth and overburden pressures increase. For this reason, depths of approximately 300 to $3,000 \mathrm{ft}$ appear to be most appropriate for the disposal horizon. 
Vertical and Horizontal Extent of Salt Deposit

The salt formation must be extensive enough so that the amount of salt surrounding the repository, i.e., the vertical and horizontal dimensions of the salt deposit, is adequate to provide protection from boundary dissolutioning processes for time periods up to one million years. The required distance depends on the analysis of a number of items, such as the total thickness and shape of the salt formation, the thickness of salt overlying the wastes, etc.

\section{Porosity and Permeability Characteristics}

Since the movement of ground water is virtually the only geologic mechanism that can transport radionuclides from a repository to the biosphere, low porosity and permeability are mandatory properties of an ideal host rock. For maximum isolation, the rocks contiguous with the disposal horizon both laterally and vertically should also be nonporous and impermeable.

\section{Homogeneity of the Disposal Horizon}

Salt formations are frequently interlayered with sedimentary materials such as clays, shales, anhydrite, etc. It is desirable that the amount and extent of these interbeds within the disposal horizon be minimal since formations with a homogeneous composition are normally excavated with a reasonable degree of facility, offer uniform thermal, chemical, and mechanical properties, and are least likely to have ground water problems. 
Tectonic Stability

The disposal horizon should underlie a region that has a stable tectonic history; that is, it has not experienced any major. occurrences of downwarp, uplift, or faulting. It should be as free as possible from known or anticipated structural phenomena. Any joints, faults, and other structural features present must be shown to be stable and must be situated such that they do not jeopardize the hydrologic integrity of the site. Dips in stratified rocks should be less than a few degrees. Sedimentary basins are noteworthy for the complete absence of intense tectonic deformation throughout the vast periods of geologic time that have elapsed since deposition of the rocks.

\section{Seismic Stability}

The repository site should underlie a region having a low seismic risk. Such a location would be expected to be remote from recorded earthquakes of greater than "moderate" intensity. Most regions having bedded or domed salt deposits have the low seismic risk required.

\section{Resource Potential}

Mineral or fuel resources such as oil, natural gas, and potash often occur in close proximity to the salt deposits of interest. Repository sites should be selected so that they do not significantly infringe on these areas of existing or potential economic value. Fortunately, this appears not to be a serious problem since the abundance and extent of salt deposits are sufficient to ensure that many areas of adequate size will remain after those areas of economic interest are removed from consideration. 


\section{Configuration of Land Surface}

Topographic relief in the area of the repository should be low enough to ensure that erosional processes do not threaten containment of the waste. Surface configuration in the area of consideration should also be suitable for the construction of the surface facilities. 


\section{PERFORMANCE CHARACTERISTICS OF WASTE REPOSITORY}

Radioactive waste placed in a geologic formation will impose a variety of transient disturbances on the natural stability of the formation. Before a particular formation (and repository design) can be certified as acceptable, a very detailed analysis of these effects must be carried out which shows that the containment of the wastes provided by the geologic formation will not be compromised in any way. The most important transient effects are thermal heating, radiation, rock deformation as the underground openings close, and migration of the small brine inclusions existing in almost all natural salt deposits.

Much of the information available on the performance characteristics of a waste repository in salt was developed during the Project Salt Vaul t* experiment. Experiments were conducted in the Carey Salt Company mine at Lyons, Kansas, from November 1965 to October 1967; however, the performance of the mine was subsequently monitored for several more years. A sketch of Project Salt Vault is shown in Figure 7 . The objectives of Project Salt Vault were (1) demonstration of waste-handliny equipment and techniques; (2) determination of possible gross effects of radiation (up to $10^{9}$ rads) on such things as hole closure, floor uplift, and salt-shattering temperature; (3) determination of possible radiolytic gas production; and (4) collection of information on creep and plastic flow of salt.

*R. L. Bradshaw and W. C. McClain, Project Salt Vault: A Demonstration of the Disposal of High-Activity Solidified Wastes in Underground Salt Mines, ORNL-4555 (Apri1 1971). (NTIS) 


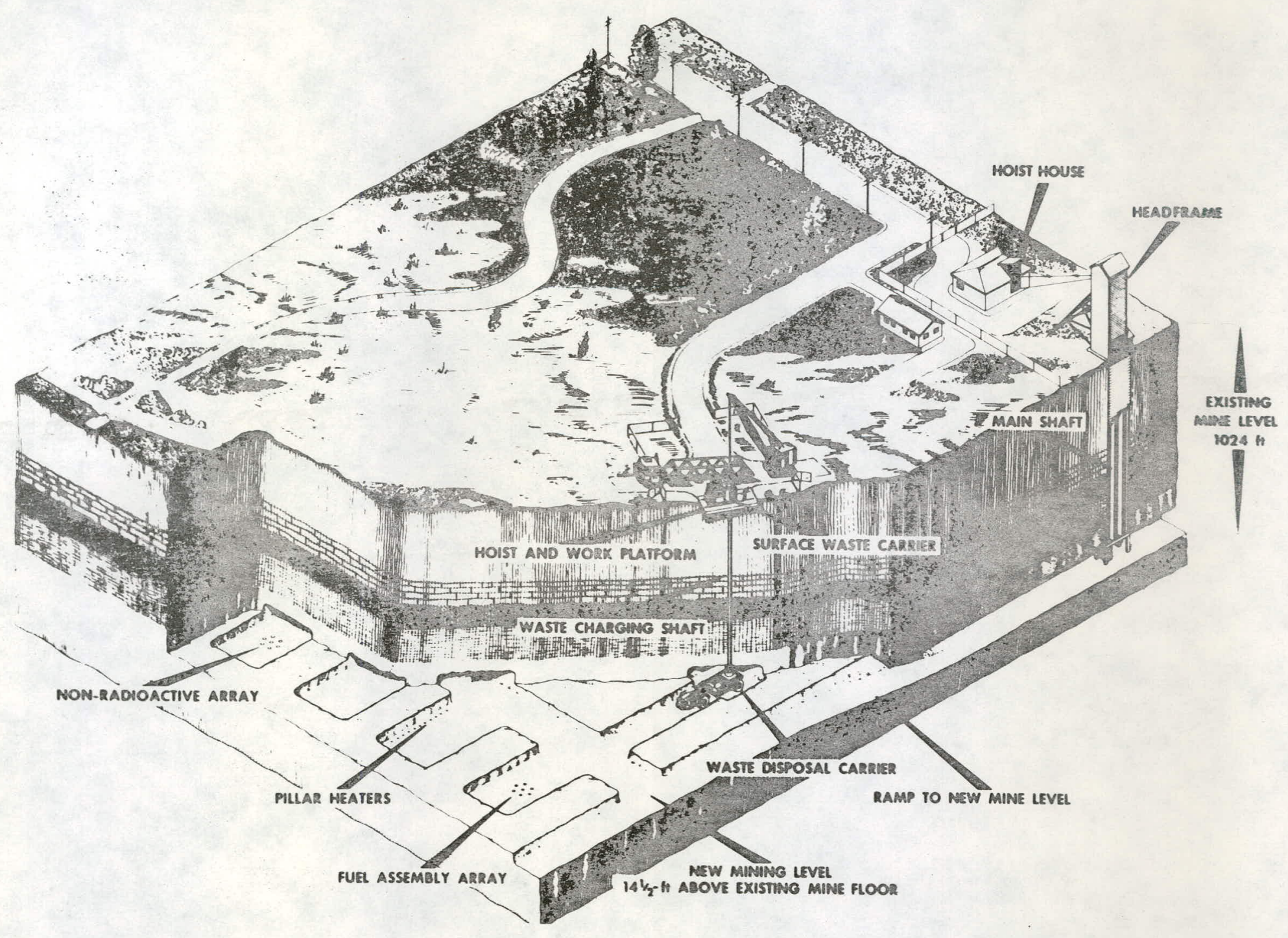

PROJECT SALT VAULT - Lyons, Kansas

Figure 7 
The objectives were accomplished by conducting experiments in four new rooms adjacent to the old workings in the mine. Simulated waste cans containing irradiated Engineering Test Reactor fuel assemblies were placed in a seven-can array in the floor of one room to study combined thermal and radiation effects. An identical array using electrical heaters only was operated in another room to study temperature effects without radiation effects. Additional rows of electric heaters were placed on both sides of a pillar to study pillar creep at elevated temperature.

A variety of instrumentation was used to measure the temperature distribution and deformations such as floor heave and room closure. Deformation measurements continued for several years after the heaters were turned off in order to project the long-term consequences of the application of heat in an underground salt formation.

Data collected during this experiment have been used to demonstrate the validity of computer programs used to predict the long-term thermal and deformational behavior of a repository in salt. Project Salt vault was the most extensive experiment ever conducted on the behavior of a salt mine under elevated temperature conditions, and the data serve as the basis for the performance characteristics of a waste repository, This information as well as considerable additional information is contained in ERDA-76-43, which is often referred to as the Technical Alternatives Document, or TAD.*

*Alternatives for Managing Wastes from Reactors and Post-Fission Operations in the LWR Fuel Cycle, Vols. 1-5, ERDA-76-43 (Play 1976). 


\section{Thermal Effects}

I will now discuss thermal effects. When high-level radioactive waste is buried in geologic formations, the heat released increases the temperature of the formation with subsequent changes in physical and chemical properties that could lead to abnormal behavior. Ultimately the heat will be transferred to the atmosphere, and the repository region will essentially return to its initial state. This return assumes that the repository design precludes excessive temperatures and temperature gradients that would adversely affect the operational safety, containment integrity, and the environment.

Thermal effects that influence the allowable temperature rises and heat release rates include: (1) thermal stability of the waste and the formation; (2) structural integrity of the mine during operations; (3) structural integrity of the entire geologic formation; (4). migration of brine or water contained in the pores of the formation;

(5) chemical reactions around the canister during the operational phase;

(6) temperature rise in any nearby aquifers; (7) temperature increases beyond the boundaries of the controlled area; and (8) heating of the earth's surface. Thermal criteria will be established to limit adverse thermal effects; these criteria will be a function of the particular formation. The temperature distributions resulting from the emplaced waste influence the rock mechanics calculations of floor heave, room closure, and roof spalling during the operational and post-operational phases. Rock mechanics calculations are discussed later. Thermal criteria in the form of maximum thernal loading $(150 \mathrm{~kW} /$ acre $)$ were developed 
by Cheverton and Turner* for disposal of high-level waste in bedded salt based on Project Salt Vault data. The criteria are generally applicable to similar salt beds.

A rise in temperature increases the speed of chemical reactions and will generally cause an increase in corrosion rates on the waste canisters or the protective sleeves while in use during the retrieval phase. These chemical reactions produce hydrogen gas (with some $\mathrm{HCl}$ and additional hydrogen by radiolysis of the brine) plus some other chemical products. This potential hazard is not a long-term one. In the operational phase it represents a hazard typical of industrial operations that are controlled by good safety and engineering practices.

\section{Radiation Effects}

A radiation effect in crystalline compounds that has caused concern is the absorption of radiation energy with subsequent storage. If a sudden release should occur, this energy could be converted to mechanical energy and produce damage to both the waste container and surroundings.

Stored radiation energy refers to that energy associated with lattice damage (displaced atoms) in a solid caused by radiation and released as heat when the damage is annealed (i.e., when the undamaged structure is restored). Most types of radiation damage are annealed when the temperature

$*$ R. D. Cheverton and W. D. Turner, Thermal Analysis of the National Radioactive Waste Repository: Progress Through March 1972, ORNL-4789 (September 1972). (NTIS) 
is increased. Damage resulting in chemical decomposition with loss of a decomposition product from the solid is, of course, not reversed by annealing.

The buildup and release behavior of radiation-induced stored energy has been investigated for several synthetic, solidified high-level waste forms. The results of this study by Roberts, Jenks, and Bopp* showed that up to $25 \mathrm{cal} / \mathrm{g}$ energy may accumulate in the waste within about 10 years following reprocessing. Extrapolation of the results to longer storage times in a geologic repository, together with available theoretical and experimental information, indicates that saturation of energy storage will occur at $50 \mathrm{cal} / \mathrm{g}$ or less for each waste type for the repository conditions. It was calculated that the temperature rise of the waste due to the sudden release of this stored energy would be less than $300^{\circ} \mathrm{C}$.

In the surrounding salt formation, under certain conditions of temperature, dose rate, dose, etc., stored energy can accumulate in the immediately adjacent salt. The experimental data and correlations show that the maximum rate (no annealing) of formation of stored energy in salt in a waste repository will be $1.4 \times 10^{-9} \mathrm{cal}^{-1} \mathrm{rad}^{-1}$. It will $^{+}$It be independent of temperature, dose rate $\left(a t<10^{8} \mathrm{rad} / \mathrm{hr}\right.$ ), dose, and

${ }^{*} F$. P. Roberts, G. H. Jenks, and C. D. Bopp, Storage and Release of Radiation Energy in Salt in Radioactive Waste Repositories, BNWL 1944 (February 1976). (NTIS)

${ }^{\dagger}$ G. H. Jenks and C. D. Eopp, Storage and Release of Radiation Energy in Radioactive Waste Repositories, ORNL-5058 (in preparation). 
type of salt: At this formation rate with no annealing, the maximum stored energy in the salt will be 50 to $60 \mathrm{cal} / \mathrm{g}$.

No external mechanism is apparent that could promote a sudden release of stored energy in the repository salt or in the contained waste by rapid heating. However, assuming a sudden, unforeseen release of the entire amount of stored energy in the waste within a canister and within the surrounding salt, it was calculated that the induced stresses would be less than those caused by the detonation of one-half pound or less of TNT.

\section{Salt Decrepitation and Brine Migration}

Now let me turn to salt decrepitation and brine migration. A bedded salt deposit is an aggregate of single. salt crystals with remnants of the antecedent brine occurring both inside the individual crystals as "brine inclusions" and as brine trapped on crystal boundaries in the aggregate. These brine inclusions are typically less than $1 \mathrm{~mm}$ in size. Brine contained in bedded salt ranges from 0.5 to $1 \%\left(\right.$ vol \%). At approximately $250^{\circ} \mathrm{C}\left(482^{\circ} \mathrm{F}\right)$, the outward force from the expansion of the "boundary brine" can overcome the forces holding an unconfined piece of aggregate together and can fracture the aggregate into a loose collection of crystals (derrepitation). The brine inclusions within the separate crystals cannot nvercome the stronger internal crystal forces at this temperature.

In an actual repository, the salt aggregate is confined. First, the overburden pressure from the many layers of rock above the salt bed does 
not allow most of the salt to decrepitate at this temperature. Secondly, a compressive pressure is created around the disposal hole as the salt expands from the waste heat. Consequently, even at the hole surface there is little decrepitation. Project Salt Vault data together with other experimental data have shown this to be the case. *

When the brine cavities are subjected to a temperature gradient, they will move either up or down the gradient. ${ }^{t}$ A cavity containing only brine and no gas will move up the gradient toward the heat source at about $5 \mathrm{~cm} /$ year for a gradient of $1{ }^{\circ} \mathrm{C} / \mathrm{cm}$ at $200^{\circ} \mathrm{C}$ while a cavity with a gas bubble may move away from the hot canisters at a similar rate. The gas may have already existed in a cavity or the bubble may be formed by decomposing the brine with radiation.

We have not identified any serious brine-related hazards or effects that cannot be counteracted by appropriate operational methods and procedures in a repository. However, experimentation is continuing to gather additional data on the amounts of brine and brine products which will be encountered in a repository, and also regarding the effects of the brine

* G. H. Jenks, Radiolysis and Hydrolys is in Salt Mine Brines, ORNL/TM-3717 (March 1972). (NTIS)

tRadioactive Waste Repositury Project: Technical Status Report for Period Ending September 30, 1971, ORNL-4751. (NTIS) 
on corrosion and on consolidation of the backfill. One objective of the electrically heated in situ experiments in salt which are being planned at Avery Island, Louisiana, is to provide this additional information.

\section{Rock Deformation}

One of the direct results of the operation of a waste repository is that the rocks in the immediate vicinity will be subjected to mechanical stresses and deformations as a result of both the underground workings and the elevated temperatures. For a repository in bedded salt, both the salt itself and the surrounding rocks will experience a sequence of transient and permanent displacements and strains. These deformations will result from the combined effects of (1) the designed closure of the mine openings, which will contribute to reconsolidation and recrystallization of the salt backfill and (2) the bulk thermal expansion and induced thermal stresses caused by the transient increase in temperature. The following remarks refer to a repository in bedded salt. Similar work is being done for a repository in domed salt.

In an effort to quantify the effects just mentioned, a series of preliminary calculations have been made using an arbitrary repository design. It was assumed that an areal mining extraction ratio of $50 \%$ would be possible and that 15-ft-high rooms could be backfilled with crushed salt up to $50 \%$ of the maximum density. After backfilling, the mining horizon will contain approximately $75 \%$ of the premining salt volume which will lead to a maximum surface subsidence of about $4 \mathrm{ft}$. after extensive plastic flow in the mine pillars. The rate of closure 
of the mine due to the plastic deformation of the salt was obtained by a modeled extrapolation of Project Salt Vault pillar deformation data and is shown as the solid line in Fig. 8. The surface subsidence behavior for this type of mine geometry and mine closure can be predicted from experience in the mining industry, especially in coal mines. If the mine closure were the only effect, a very broad, flat, saucer-shaped subsidence region would be created over the repository site.

The thermal expansion effects by themselves can be estimated by integrating the predicted temperature profiles and applying the coefficient of thermal expansion of the various rock types. The resuit of this calculation, based on representative values of the coefficients of thermal expansion, is shown as the dashed line in Fig. 8. Neglecting all other effects as before, the thermal expansion of the entire rock column above and to a considerable depth below the mine would cause the ground surface to first rise gradually, reaching a maximum of a little over 5 ft after about 200 years, after which the surface would very slowly return to its original elevation as the heat load is dissipated. This process would require several thousand years to complete.

The actual behavior of the ground surface will be a resultant of the two effects. Using the two curves of Fig. 8, it can be seen that the downward subsidence is partially cancelled by the upward thermal expansion for the first 30 to 40 years. Thereafter, the expansion effects exceed the subsidence, producing a net uplift of the surface which reaches a maximum of about $1 \mathrm{ft}$ slightly over 200 years after initial operation of the repository. Following this maximum, the 


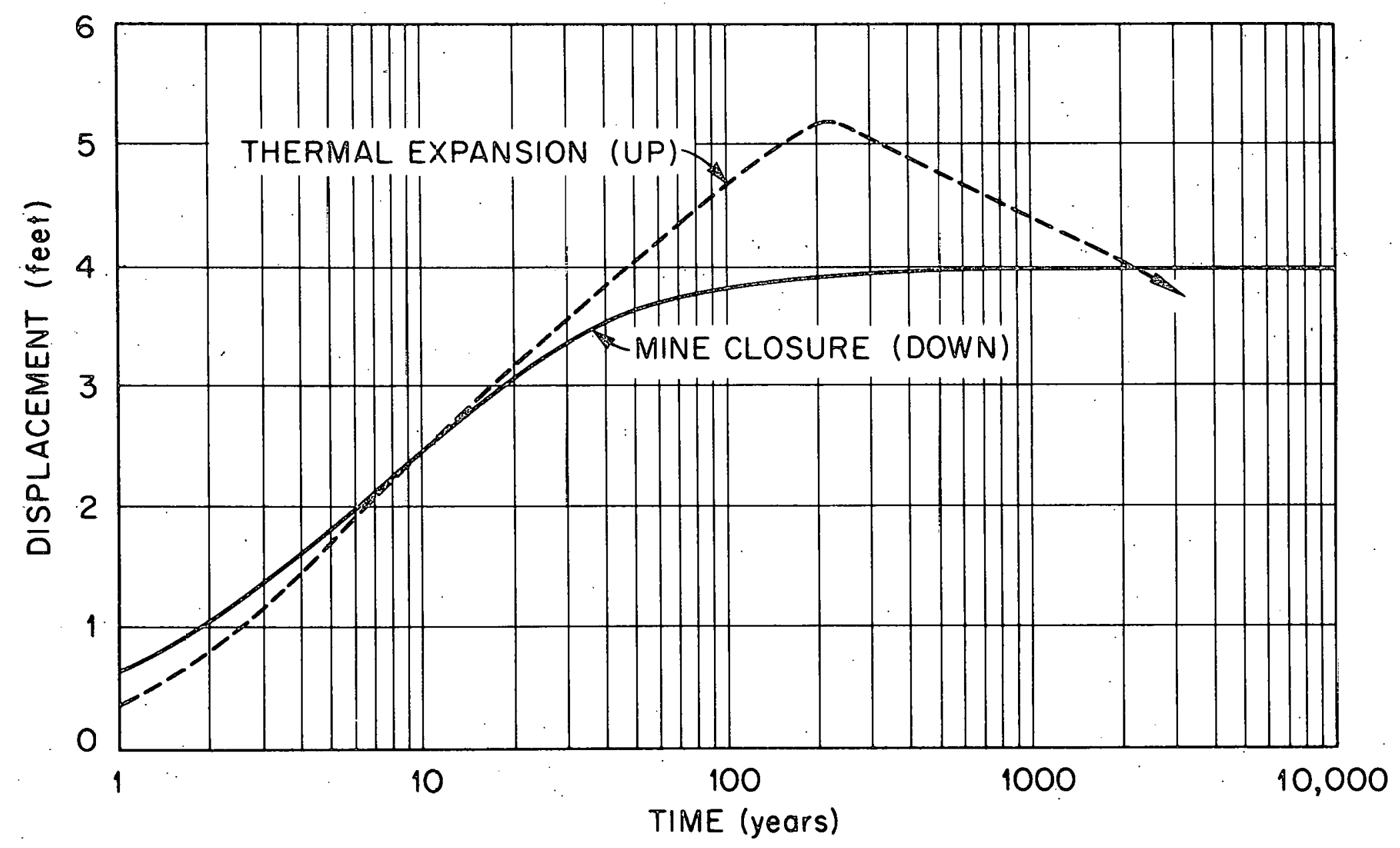

Comparison of Mine Closure and Thermal Expansion.

Figure 8 
surface will very slowly subside, pass through its original position, and eventually (thousands of years later) reach a final position about $4 \mathrm{ft}$ below its original elevation.

It is difficult to believe that the development of a broad, slight subsidence at such a slow pace as that just described would create any adverse situation on the surface. The principal factor, however, is the very slow rate of deformation and, consequently, the time available for adjustments to take place. For example, this average rate of subsidence is only about three times greater than the estimated rate of current surface lowering due to natural erosional processes over a typical bedded salt deposit.

The primary concern with regard to the rock deformations involves the displacements and strains that must be absorbed by the overlying shales, principally in the transition zone above the boundaries of the repository. Specifically, we are interested in whether those deformations, in combination with the increased temperatures and any physical alteration resulting therefrom, represent a potential mechanism whereby the integrity of the geologic confinement may be breached. There is evidence from the mining industry to suggest that in situ rocks can easily absorb strains of the anticipated magnitude. Furthermore, over long time spans such as the thousands of years available in this case, shale rocks are capable of slow plastic deformation, which further drasticaliy reduces the potential for widespread fracturing. The 
possible effects of rock deformations (from whatever source) on the integrity of the containment are being studied in general and will be evaluated in detail as part of the site-specific program.

\section{Oklo Phenomena}

Some confidence in the ability of geologic materials to contain radioactive materials for very long time periods can be derived from examination of the recently discovered natural nuclear reactor in the Oklo ore deposit in Gabon, West Africa. It has been deduced that about two billion years ago, at least four to six separate zones in this deposit spontaneously went "critical" and sustained nuclear chain reactions for over a half-million years, producing and subsequently containing about 10,000 pounds of fission products plus about 4,000 pounds of plutonium. This natural reactor operated for about 600,000 years with an average thermal power $25 \mathrm{~kW}$.

The 0klo reactor site represents a case history, showing that nature has successfuily stored six metric tons of reactor products for two billion years, nearly all the heavy elements and most of the fission products having remained in place. 


\section{DISTRIBUTION}

1-27. U. S. Energy Research and Development Administration

J. J. Schreiber (20), ORO

J. Ellis, GJ

T. B. Hindman, SR

N. H. Mackay, AL

R. Nack, $\mathrm{CH}$

D. T. Schueler, Jr., NV

D. J. Squires, RL

G. Wehman, ID

28-29. ORGDP Administrative Offices

C. J. Parks

$R$. A. Winkel

30-39. Oak Ridge National Laboratory.
A. A. Brooks
F. L. Culler
D. E. Ferguson
G. H. Jenks
G. H. Llewellyn
H. Postma
E: G. St. Clair
D. B. Trauger
J. R. Weir
F. C. Zapp

40-96. Office of Waste Isolation

W. R. Andrews

J. M. Asher

J. T. Atherton

K. K. Aydelotte

M. L. Bennett

R. Blumberg

A. L. Boch

G. D. Brunton

H. C. Claiborne

L. B. Cobb

L. R. Dole

P. D. Fairchild

W. A. Goldsmith

I. N. Kaplan

R. K. Kibbe

R. B. Laughon

T. F. Lomenick

R. S. Lowrie

S. C. Matthews
L. L. McCauley

W. C. McClain

J. M. Morrison

J. R. Palmer

W. H. Pechin

A. S. Quist

D. B. Roe

H. N. Rosenberg

J. E. Russell

R. L. Shoup

D. W. Turner

J. E. Vath

C. D. Zerby

OWI Records - 25

97. Operations Analysis and Planning

J. T. Bradbury

98. Paducah

C. C. Hopkins

99. Technical

W. J. Wilcox, Jr.

100-106. Y-12 Plant

J. M. Case

H. I. Cobert

J. D. Griffin

R. F. Hibbs

G. R. Jasny

P. R. Vanstrum

Plant Records - RC

107-112. Geologic Review Group

J. H. Crawford

S. N. Davis

F. A. Donath

J. C. Frye

E. F. Gloyna

K. B. Krauskopf 